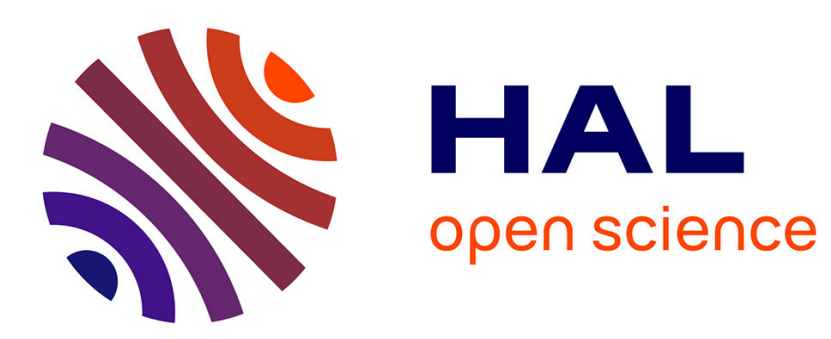

\title{
A new tool for plant cell biology: in vivo antibody uptake in plant protoplasts
}

\author{
Christian Brière, Henri Barthou, Michel Petitprez
}

\section{To cite this version:}

Christian Brière, Henri Barthou, Michel Petitprez. A new tool for plant cell biology: in vivo antibody uptake in plant protoplasts. Plant Cell Reports, 2004, 22, pp.878-884. 10.1007/s00299-004-0788-9 . hal-00023082

\section{HAL Id: hal-00023082 \\ https://hal.science/hal-00023082}

Submitted on 20 Apr 2006

HAL is a multi-disciplinary open access archive for the deposit and dissemination of scientific research documents, whether they are published or not. The documents may come from teaching and research institutions in France or abroad, or from public or private research centers.
L'archive ouverte pluridisciplinaire HAL, est destinée au dépôt et à la diffusion de documents scientifiques de niveau recherche, publiés ou non, émanant des établissements d'enseignement et de recherche français ou étrangers, des laboratoires publics ou privés. 


\section{A new tool for plant cell biology: In vivo antibody uptake in plant protoplasts}

Christian Briere, Henri Barthou, Michel PetitPrez

Laboratoire "Biotechnologie et Amélioration des Plantes", INP-ENSAT, BP 107 Auzeville F-31326 Castanet-tolosan, France

E-mail: briere@ensat.fr

Tel.: +33(0)562193590

Fax: +33(0)562193589

\section{Abstract}

We report on the in vivo uptake of antibodies into plant protoplasts. It is shown by immunofluorescence that when protoplasts of sunflower, Arabidopsis or tobacco were incubated in vivo with an antibody, this antibody was detected in the cytoplasm and/or the nucleus, depending on the location of the target protein. Furthermore, when protoplasts were cultured in the presence of antibodies specific effects were observed. Incubation with antibodies raised against $\mathrm{p} 34^{\mathrm{cdc} 2}$ led to a strong inhibition of the division rate and a decrease of the average DNA content of protoplasts. With antibodies against HaWLIM1, a LIM domain protein of the CRP type, a negative effect on actin organization was observed. It is concluded that antibodies can penetrate in vivo into plant protoplasts and thus may be used as powerful tools for the study of protein function.

Key words: plant protoplasts, antibody uptake, protein function 


\section{Introduction}

Antibodies are widely used for immunodetection and immunolocalization of proteins in animal and plant cells. The usual protocols for immunostaining require fixation and permeabilization of cells or tissues before antibody binding, and thus do not apply to living cells. Beside localization of proteins in cells or tissues, antibodies can also provide interesting clues regarding the function of secreted proteins.

In animal cells, although antibody permeability appears to be the major barrier for antibody accretion in tumors (Zhu et al. 1997), antibodies have been widely used in immunotherapy and immunodetection (Kairemo et al. 1996; Adamus et al. 1997;

Hjelstuen et al. 1998; Shutian et al. 2000; Halin et al. 2002). In vivo uptake of an antiCD30/saporin immunotoxin by rat liver cells gave encouraging results in the treatment of refractory Hodjkin's disease (Batelli et al. 1994). More recently, antibodies raised against nucleus components have been used for in vivo detection of intervertebral disk injury (Kairemo et al. 2001). Antibody uptake assays have also been used to demonstrate internalisation of proteins (Abe et al. 2000; Doedens and Black 2000; Walter et al. 2001) and to study the function of proteins: in T lymphocyte, anti-CD3 and anti-CD28 monoclonal antibodies were shown to mimic CD28 costimulation (Lai et al. 1999).

In plants, the penetration of large molecules into cells is strongly limited by the presence of the cell wall, whose porosity limit for globular proteins has been estimated at about $120 \mathrm{kDa}$ (Baron-Epel et al. 1988). To date, in vivo experiments with antibodies used as blocking agents were limited to studies on transmembrane receptors in symbiosomes (Moreau et al. 2002) or in protoplasts (Barbier-Brygoo et al. 1989; Barbier-Brygoo et al. 1991; Rück et al. 1993; Leonhardt et al. 2001), or to the use of Fab fragments of lower molecular weight (Gehring et al. 1998). In this article, we report on the penetration of antibodies into living protoplasts and on their use as blocking agents to study the function of intracellular target proteins.

\section{Material and methods}

\section{Plant material}

\section{Sunflower protoplasts}

Seeds of sunflower (Helianthus annuus L., genotype EMIL Pioneer France Maïs) were sterilized in $5 \%$ calcium hypochloride for $20 \mathrm{~min}$, then rinsed in sterile water and cultivated on MS medium (Murashige and Skoog 1962) at $25^{\circ} \mathrm{C}$ under a 16 -hour photoperiod (light intensity $25 \mu$ E.m-2.s-1). Protoplasts were isolated from 8-day old plantlet hypocotyls according to the protocol of Chanabé et al. (1989). After purification, protoplasts were embedded at a final density of $1.510^{5} . \mathrm{mL}^{-1}$ in TLD medium (Chanabé et al. 1991) containing 0.5\% Sea Plaque agarose (FMC Bioproduct, Rockland, USA), and before solidification small drops $(40 \mu 1)$ of this mix were spread on poly-L-lysine (Sigma)-coated coverglasses. After solidification of the drops, embedded protoplasts were submerged in $1 \mathrm{~mL}$ of TLD medium and cultured in the dark at $25^{\circ} \mathrm{C}$. 


\section{Arabidopsis protoplasts}

Arabidopsis cell suspension was subcultured weekly by inoculating with $1.5 \mathrm{~g}$ cells $300 \mathrm{ml}$ Gamborg medium (Gamborg et al. 1968) supplemented with $20 \mathrm{~g} / 1$ sucrose and $2.5 \mu \mathrm{M} 2,4 \mathrm{D}, \mathrm{pH} 5.7$. For protoplasting, $300 \mathrm{ml}$ of the same medium were inoculated with $5 \mathrm{~g}$ cells four days before the experiment. Protoplasts were then prepared as described in Neuhaus and Boevink (2001). After purification, protoplasts were embedded in solid medium $(0.5 \%$ agarose in $10 \mathrm{mM}$ Hepes and $550 \mathrm{mM}$ Sorbitol, $\mathrm{pH}$ 7.3) as described above and submerged in $1 \mathrm{~mL}$ Hepes buffer.

\section{Tobacco protoplasts}

Tobacco cell lines (Nicotiana tabacum L. cv Bright Yellow BY-2) were grown in Linsmaier and Skoog liquid medium (Linsmaier and Skoog 1965) supplemented with $30 \mathrm{~g} / 1$ sucrose and $0.2 \mu \mathrm{g} / \mathrm{ml} 2,4 \mathrm{D}$. Cultures were kept in the dark at $25^{\circ} \mathrm{C}$ on a gyratory shaker (130rpm) and subcultured every two weeks with a $2 \%$ inoculum. Protoplasts were prepared from 7 day-old cell cultures. After filtration on a $37 \mu \mathrm{m}$ Nytal membrane, cells were incubated ( $4 \mathrm{~h}$ in the dark at $37^{\circ} \mathrm{C}, 44 \mathrm{rpm}$ ) in a Tris-Mes buffer (Mes $25 \mathrm{mM}$, Sorbitol 0.6M, pH 5.5) supplemented with: $40 \mathrm{mg} / \mathrm{g}$ pectolyase $\mathrm{Y} 23,200 \mathrm{mg} / \mathrm{g}$ cellulase RS, $40 \mathrm{mg} / \mathrm{g}$ driselase, $200 \mathrm{mg} / \mathrm{g}$ BSA. After washing in Hepes buffer (Hepes $25 \mathrm{mM}$, Sorbitol 0.6M, pH 6.7), protoplasts were resuspended in $10 \mathrm{ml}$ Hepes buffer supplemented with $10 \%$ Ficoll, and $3 \mathrm{ml}$ of Hepes buffer were delicately added on top of the cell suspension. After $5 \mathrm{~min}$ centrifugation at $100 \mathrm{xg}$, protoplasts were taken out from the interface and washed two times in $10 \mathrm{ml}$ Hepes buffer. After purification, protoplasts were embedded in solid medium $(0.5 \%$ agarose in Hepes buffer) as described above and submerged in $1 \mathrm{~mL}$ Hepes buffer before use.

\section{Antibodies}

Polyclonal antibodies against the sunflower protein HaWLIM1 were obtained by CovaLab (Lyon, France) by immunization of one rabbit against two synthetic peptides designed in regions of the protein non homologous to other LIM proteins. The immune serum was obtained after 74 days and used at a final dilution 1:1000. Other antibodies tested were rabbit polyclonal antibodies or mouse monoclonal antibodies (Table 1). For immunostaining, polyclonal (Donkey) anti-Rabbit IgG FITC-conjugate (Amersham) or polyclonal anti-mouse IgG FITC-conjugate (Amersham) were used at a final dilution $1: 50$.

\section{Antibody uptake and staining of living protoplasts}

Protoplasts (embedded in agarose on coverglasses) were in vivo incubated for $3 \mathrm{~h}$ at room temperature in the presence of unlabelled antibody. After incubation, protoplasts were rinsed $5 \mathrm{~min}$ in $1 \mathrm{~mL}$ fresh culture medium and next fixed for $1 \mathrm{~h}$ at room temperature by $2 \%$ paraformaldehyde and $0.03 \%$ glutaraldehyde in $50 \mathrm{mM}$ Pipes buffer supplemented with 5mM EGTA, $5 \mathrm{mM} \mathrm{MgSO}_{4}$ and $0.08 \%$ Igepal-ca630 (Sigma). After washing three times in the same buffer, protoplasts were incubated for $10 \mathrm{~min}$ in PBS $10 \mathrm{mM}$ with $1 \mathrm{mg} / \mathrm{ml} \mathrm{NaBH} 3 \mathrm{CN}$, next rinsed in $\mathrm{TBS}_{-} \mathrm{Mg}^{2+}$ (Tris $10 \mathrm{mM}, \mathrm{MgCl}_{2} 30 \mathrm{mM}$ ) for $10 \mathrm{~min}$ and in TBS-BSA (Tris $20 \mathrm{mM}, \mathrm{NaCl} 150 \mathrm{mM}$ supplemented with $1 \mathrm{mg} / \mathrm{ml}$ 
BSA) for $10 \mathrm{~min}$. Protoplasts were then incubated for $2 \mathrm{~h}$ at room temperature with FITC-labelled secondary antibodies (dilution 1:50). After rinsing three times 10min in TBS-BSA, coverglasses were mounted in an anti-fading buffer (Citifluor, Link Analytical). For negative controls, protoplasts were fixed and stained without in vivo preincubation with antibody.

\section{Microscopy and image analysis}

For conventional fluorescence microscopy, observations of immunostained protoplasts were made with a Leitz Laborlux microscope (Leica, Heidelberg, Germany) equipped for epifluorescence illumination and with Leica filter block I2 (excitation BP450-490 and emission LP520). Images were acquired using a PL APO 40x/1.32 oil objective lens and a digital camera Coolpix 950 (Nikon, Japan).

Confocal observations were made with a TCS SP2 confocal laser microscope (Leica). Image acquisition was achieved with a HCX PL APO 40x/1.25 Leica objective lens in scan mode and image averaging of 3 frames. For FITC the $488 \mathrm{~nm}$ line of an argon laser was used and the emission window set to $510-530 \mathrm{~nm}$.

For quantitative analysis of DNA contents, protoplasts were stained with Hoechst and observed on a DMIRBE microscope (Leica, Heidelberg, Germany) with filter block A (excitation BP 340-380 and emission LP 430). Images were acquired with a Colorview CCD camera (Photonics Science, UK) and then analysed with Image Pro Plus imaging software (Mediacybernetics, Silver Spring, MD, USA).

\section{Results}

\section{In vivo antibody uptake in protoplasts}

The uptake of antibodies was studied with unlabelled antibodies raised against specific proteins: the sunflower LIM domain protein HaWLIM1, spectrin (chicken), calreticulin (human) and $\mathrm{p} 34^{\mathrm{cdc} 2}$ (PSTAIRE). Protoplasts in culture were incubated with unlabelled antibodies for 3 hours. After rinsing with fresh culture medium, they were fixed and the presence of antibodies inside protoplasts was then revealed by immunostaining with FITC-labelled secondary antibodies.

HaWLIM1 is a protein of unknown function expressed in all organs of sunflower (Mundel et al. 2000), which presents a dual localisation, nuclear and cytoplasmic. Protoplasts pre-incubated with anti-HaWLIM1 were nearly all labelled (Fig. 1). A clear nuclear labelling and a dotted cytoplasmic pattern were observed (Fig.2a), in accordance with published data (Brière et al. 2003).

With anti-chicken spectrin antibodies a network of thin filaments could be seen (Fig. $2 b)$. This pattern corresponds well to the expected localization of spectrin, known to associates with actin arrays and ER aggregates (Braun 2001).

In animal, calreticulin is known to localize in the ER lumen (Michalak et al. 1992). In preincubated sunflower protoplast, anti-calreticulin antibodies were found in the nucleus and also along filaments (Fig.2c). Such pattern is in good accordance with the expected localization of this protein.

The PSTAIRE epitope is shared by all cdc 2 proteins and antibodies against PSTAIRE recognize a cdc2-like protein which is localized mainly to the nucleus in plant cells 
(Colasanti et al. 1993). In sunflower protoplasts, anti-cdc2 antibodies were detected predominantly in the nucleus and more weakly in the cytoplasm, as a diffuse fluorescence (Fig.2d).

Surprisingly, anti- $\alpha$-tubulin monoclonal antibody was detected only very weakly in sunflower protoplasts, mainly in the nucleus (Fig.2e).

In control experiments, when protoplasts were stained without preincubation with antibodies they showed no fluorescent labelling (Fig. 2f).

In order to test the effect of washing after antibody incubation, protoplasts were incubated with anti-HaWLIM1 for one day, then rinsed twice 20min in 2ml TLD medium before fixation and immunostaining. A clear labelling was still observed as described above.

Antibody uptake experiments were also carried out with Arabidopsis and tobacco protoplasts using the same protocol. As with sunflower protoplasts, when they were preincubated in vivo with anti-HaWLIM1 or anti-spectrin antibody, Arabidopsis protoplasts (Fig. 3a and 3b) and tobacco protoplasts (Fig. 4a and 4b) showed a strong cytoplasmic and/or nuclear labelling. In contrast to the observations made in sunflower protoplasts, an uptake of the anti- $\alpha$-tubulin antibody was observed in Arabidopsis and tobacco (Fig. 3c and 4c). The cytoplasm and the nucleus were clearly labelled, but without displaying a clear network pattern as it was expected for tubulin.

\section{Antibodies can be used as blocking agents}

In order to demonstrate the possibility of using antibodies as blocking agents of target proteins in protoplasts, two polyclonal antibodies were tested: one against $\mathrm{p} 34^{\mathrm{Cdc} 2}$ and one against HaWLIM1.

$\mathrm{p} 34^{\mathrm{Cdc} 2}$ is known to be involved in the regulation of the cell cycle (Draetta and Beach 1988). Blocking the function of this protein with an antibody by inhibiting its activation by cyclins should have an inhibitory effect on the cell cycle and thus on protoplast division. Antibody was added to the culture medium of sunflower protoplasts at day 0 (immediately after protoplast purification). Protoplasts were then cultured at $25^{\circ} \mathrm{C}$ in the dark. A rabbit preimmune antiserum was used as negative control.

The viability of protoplasts was assessed by FDA labelling after 3 days in culture in the presence of anti-Cdc2 antibody. For dilutions higher than 1:200 the presence of antiCdc2 antibody in the culture medium had no effect on protoplast viability (Fig. 5). But for lower dilutions, a dose dependent decrease of viability was observed.

The division rate of protoplasts was then assessed after one week in culture. In control cultures the division rate was found similar to that of protoplasts cultured in normal conditions (i.e. without addition of antiserum). With anti-Cdc2, a dose-dependent effect was observed: the division rate strongly decreased in the presence of anti-Cdc 2 antibody (Fig. 5). With dilution 1:1000 the proportion of divided protoplasts was less than $50 \%$ of the control and with dilution 1:200 the division process was nearly completely blocked. For lower dilutions, no division was observed, but this may be due to the decrease of viability.

In order to correlate the inhibition of the division rate with the progression of the cell cycle, the nuclear DNA content of protoplasts cultured in the presence of anti-Cdc2 antibody (dilution 1:500) was assessed by DNA staining with Hoechst. The fluorescence of labelled nuclei was significantly lower in anti-Cdc2 treated protoplasts than in the control. This difference was maximum at culture day 6 (Fig. 6) where a high 
proportion of nuclei with a high DNA content was observed in control protoplasts but nearly none in treated protoplasts. This correlates well with the division kinetics of sunflower protoplasts where the maximum rate of cell division is reached after about 6 days of culture in control conditions.

HaWLIM1 function is not yet known in sunflower, but LIM domain proteins of the CRP type, which HaWLIM1 belongs to, are thought to be involved in the organization of the actin cytoskeleton (Bach 2000). In 1 day-old control protoplasts, actin organization, studied by immunolabelling, revealed the presence of a cortical array of microfilaments connected to the nucleus by cytoplasmic actin wires. In protoplasts cultured with anti-HaWLIM1 antiserum (dilution 1:1000) for one day, well organized actin arrays and actin wires were found at a significantly lower frequency $(\mathrm{P}=0.01)$ than in control populations (Table 1). Furthermore, after 4 days of culture with antiHaWLIM1, the plating efficiency of protoplasts was significantly increased $(\mathrm{P}=0.01)$ as compared to the controls (Table 1). Although this latter result cannot be related to a known function of the protein, the effect of anti-HaWLIM1 on actin organization corresponds well to bibliographic data.

These assays clearly show that addition in protoplasts cultures of antibodies raised against specific proteins leads to biological effects which would be expected from an inhibition of the protein functions: arresting the division process, in the case of $\mathrm{p} 34^{\mathrm{Cdc} 2}$, or actin array disorganization, in the case of HaWLIM1.

\section{Discussion}

The results described above present several evidences that antibodies may enter in vivo into plant protoplasts and thus can be useful tools for functional studies of target proteins.

Immunofluorescence studies coupled with confocal microscopy gave direct evidences of antibody penetration into living protoplasts. The four polyclonal antibodies tested in this work were found, after a few hours, inside sunflower, Arabidopsis or tobacco protoplasts cultured in the presence of the antibody. They were detected in nearly all protoplasts (cf. Fig. 1). Considering that the viability of freshly isolated protoplasts exceeds $90 \%$, this means that antibodies were able to enter into living protoplasts and not only in dead ones. It could be argued that residual antibodies bound to membrane proteins entered into protoplasts during the fixation process. But increasing the duration and the volume of washing did not suppress the labelling. Thus it is unlikely that the observed labelling was due to an experimental bias.

Furthermore, although it was difficult to assess the efficiency of the uptake, in all cases a clear cytoplasmic and/or nuclear labelling of living protoplasts was observed, generally in a good agreement with the expected pattern of the target protein. Thus, antibodies which penetrate into plant protoplasts are also able to recognize their targets. However the ability of antibodies to enter into protoplasts appears to depend on the antibody itself and on the protoplasts origin. Monoclonal antibodies such as anti- $\alpha-$ tubulin or anti-actin (result not shown) did not penetrate or only very weakly in sunflower protoplasts. In contrast, in Arabidopsis or tobacco protoplasts, an uptake of anti- $\alpha$-tubulin was clearly observed, although not showing the expected network of tubulin. We may hypothesize that the antibody did not enter into protoplasts (e.g. sunflower) or that the presence of antibody prevents the formation of a stable network 
structure. Despite the apparent dependence on antibody and protoplast origins, these results provide clear evidences that antibodies are able to penetrate in vivo in plant protoplasts.

Indirect evidences of antibody uptake come also from the results of biological assays. When anti-cdc 2 antibody was added to the culture medium, the division rate of protoplasts was inhibited and the nuclear DNA content was decreased. Such an effect was not observed with a preimmune serum or with another antibody such as antiHaWLIM1 antibody, which showed an opposite effect on protoplast division. Inhibition of protoplast division corresponds exactly to the effect expected from an inactivation of the $\mathrm{Cdc} 2 \mathrm{a}$ protein kinase, a plant homolog of $\mathrm{p} 34^{\mathrm{cdc} 2}$ which appears to have a principal role in cell-cycle control in yeast (Lewin 1990; Reed 1991). In Arabidopsis, it has been observed that a defect in the $C d c 2 a$ gene abolished cell division (Hemerly et al. 1995) exactly as did anti-cdc2 in sunflower protoplasts. In addition, knowing that Cdc2a activity starts at late G1 (Mironov et al. 1999), the reduction of DNA content in anticdc2 treated protoplasts may well correspond to an arrest of the G1/S transition resulting from the binding of the antibody to Cdc2a and the subsequent inactivation of the protein. Experiments with the anti-HaWLIM1 antibody are also quite interesting. Although the exact function of HaWLIM1 was not known, its homology with CRP proteins suggests a role in the actin cytoskeleton regulation. The disorganization of actin in protoplasts incubated with anti-HaWLIM1 is in good agreement with an inhibition of the protein function by the antibody.

The mechanism by which antibodies may enter into a living cell through the plasma membrane is largely unknown. In plant protoplasts, it has been shown the occurrence of constitutive endocytosis (Kubitscheck et al. 2000), strongly enhanced by an increase of the osmotic pressure. But depolymerising actin microfilaments with latrunculin $\mathrm{B}$, known to inhibit endocytosis, did not prevent antibody uptake in sunflower protoplasts (result not shown). Thus, other mechanisms are to be invoked. The plasma membrane of protoplasts is highly perturbed by protoplast preparation, and its permeability properties may be very different from that of intact cells.

In conclusion, besides their standard use in immunocytology experiments to determine the location of proteins, antibodies can also be used to block or to enhance the effect of proteins in plants, as already demonstrated in animal cells. The presence of the cell wall which constitutes a major barrier to the penetration of macromolecules inside plant cells may be overcome by working with protoplasts. In some extent, the necessity to work with protoplasts might be considered as a limitation of the method. Nevertheless, protoplasts constitute a very useful simplified system for functional studies at the cell level. With the development of proteomic approaches which will lead to the discovery and the sequencing of numerous new proteins, the use of antibodies as blocking agents in protoplasts should provide helpful clues for the function of these proteins in plants.

\section{Acknowledgements}

The authors thank Philippe Anson and Marie-Josée Tavella for their technical assistance in plant culture and protoplast preparation. 


\section{References}

Abe Y, Nakayama K, Yamanaka A, Sakurai T, Goto K (2000) Subtype-specific trafficking of endothelin receptors. J. Biol. Chem. 275: 8664-8671.

Adamus G, Machnicki M, Seigel GM (1997) Apoptotic retinal cell death induced by antirecoverin autoantibodies of cancer-associated retinopathy. Invest. Ophtalm. Vis. Sci. 38: 283-291.

Bach I (2000) The LIM domain: regulation by association. Mech. Dev. 91: 5-17.

Barbier-Brygoo H, Ephritikhine G, Klämbt D, Ghislain M, Guern J (1989) Functional evidence for an auxin receptor at the plasmalemma of tobacco mesophyll protoplasts. Proc. Natl. Acad. Sci. USA 86: 891-895.

Barbier-Brygoo H, Ephritikhine G, Klämbt D, Maurel C, Palme K, Schell J, Guern J (1991) Perception of the auxin signal at the plasma membrane of tobacco mesophyll protoplasts. Plant J. 1: 83-93.

Baron-Epel O, Charyal PK, Schindler M (1988) Pectins as mediators of wall porosity in soybean cells. Planta 175: 389-395.

Batelli MG, Buonamici L, Bolognesi A, Stirpe F (1994) In vivo and in vitro uptake of an anti-CD30/saporin immunotoxin by rat liver parenchymal and nonparenchymal cells. Hepatology 20: 940:947.

Braun M (2001) Association of spectrin-like proteins with the actin-organized aggregate of endoplasmic reticulum in the Spitzenkorper of gravitropically tip-growing plant cells. Plant Physiol 125: 1611-1619.

Brière C, Bordel AC, Barthou H, Jauneau A, Steinmetz A, Alibert G, Petitprez M (2003) Is the LIM-domain protein HaWLIM1 associated with cortical microtubules in sunflower protoplasts? Plant Cell Physiol 44: 1055-1063.

Chanabé C, Burrus M, Alibert G (1989) Factors affecting the improvement of colony formation from sunflower protoplasts. Plant Sci. 64: 125-132.

Chanabé C, Burrus M, Bidney D, Alibert G (1991) Studies on plant regeneration from protoplasts in the genes Helianthus. Plant Cell Rep. 9: 635-638.

Colasanti J, Cho SO, Wick S, Sundaresan V (1993) Localization of the functional p34cdc2 homolog of maize in root tip and stomatal complex cells: association with predicted division sites. Plant Cell 5: 1101-1111.

Doedens JR, Black RA (2000) Stimulation-induced down-regulation of tumor necrosis factor-alpha converting enzyme. J. Biol. Chem. 275: 14598-14607.

Draetta G, Beach D (1988) Activation of cdc2 protein kinase during mitosis in human cells: cell cycle dependent phosporylation and subunit rearrangement. Cell 54: 17-26.

Gamborg OL, Miller RA, Ojima K (1968) Nutrient requirements of suspension cultures of soybean root cells. Exp. Cell Res. 50: 151-158.

Gehring CA, McConchie RM, Venis MA, Parish RW (1998) Auxin-binding-protein antibodies and peptides influence stomatal opening and alter cytoplasmic pH. Planta 205: 581-586.

Halin C, Niesner U, Villani ME, Zardi L, Neri D (2002) Tumor-targeting properties of antibody-vascular endothelial growth factor fusion proteins. Int. J. Cancer 102: 109-116.

Hemerly A, Engler Jde A, Bergounioux C, van Montagu M, Engler G, Inze D, Ferreira P (1995) Dominant negative mutants of the Cdc2 kinase uncouple cell division from iterative plant development. EMBO J. 14: 3925-3936.

Hjelstuen MH, Rasch-Halvorsen K, Bruland OS, De L. Davies C (1998) Uptake, penetration, and bibding of monoclonal antibodies with increasing affinity in human osteosarcoma multicell spheroids. Anticancer Res. 18: 31533161.

Kairemo KJA, Karnani P, Jekunen AP (1996) Modulation of antibody kinetics by the cell membrane active agent Tween 80 in vivo. Anticancer Res. 16: 3542-3550.

Kairemo KJA, Lappalainen AK, Kaapa E, Laitinen OM, Hyytinen T, Karonen SL, Gronblad M (2001) In vivo detection of intervertebral disk injury using a radiolabeled monoclonal antibody against keratan sulfate. J. Nuclear Med. 42: 476-482.

Kubitscheck U, Homann U, Thiel G (2000) Osmotically evoked shrinking of guard-cell protoplasts causes vesicular retrieval of plasma membrane into the cytoplasm. Planta 210: 423-431.

Lai JH, Ho LJ, Kwan CY, Chang DM, Lee TC (1999) Plant alkaloid tetrandrine and its analog block CD28costimulated activities of human peripheral blood $\mathrm{T}$ cells: potential immunosuppressants in transplantation immunology. Transplantation 68: 1383-1392.

Leonhardt N, Bazin I, Richaud P, Marin E, Vavasseur A, Forestier C (2001) Antibodies to the CFTR modulate the turgor pressure of guard cell protoplasts via slow anion channels. FEBS Lett 494: 15-18.

Lewin B (1990) Driving the cell cycle: M phase kinase, its partners, and substrates. Cell 61: 743-752.

Linsmaier EM, Skoog F (1965) Organic growth factor requirements of tobacco tissue cultures. Physiol. Plant. 18: 100-127.

Michalak M, Milner RE, Burns K, Opas M (1992) Calreticulin. Biochem J 285 ( Pt 3): 681-692.

Mironov V, De Veylder L, Van Montagu M, Inze D (1999) Cyclin-dependent kinases and cell division in plants - The nexus. Plant Cell Rep. 11: 509-521.

Moreau S, Thomson RM, Kaiser N, Trevaski B, Guerinot ML, Udvardi MK, Puppo A, Day DA (2002) GmZip encodes a symbiosis-specific zinc transporter in soybean. J. Biol. Chem. 277: 4738-4746.

Mundel C, Baltz R, Eliasson A, Bronner R, Grass N, Krauter R, Evrard JL, Steinmetz A (2000) A LIM-domain protein from sunflower is localized to the cytoplasm and/or nucleus in a wide variety of tissues and is associated with the phragmoplast in dividing cells. Plant Mol Biol 42: 291-302. 
Murashige T, Skoog F (1962) A revised medium for rapid growth and bioassays with tobacco tissue culture. Physiol. Plant. 15: 473-497.

Neuhaus J-M, Boevink P (2001) The fluorescent protein (GFP) as reporter in plant cells. In Plant Cell Biology. Edited by Hawes C and Satiat-Jeunemaitre B pp. 338. Oxford University Press

Reed SI (1991) G1-specific cyclins: in search of an S-phase-promoting factor. Trends Gen. 7: 95-99.

Rück A, Palme K, Venis MA, Napier RM, Felle HH (1993) Patch-clamp analysis establishes a role for an auxin binding protein in the auxin stimulation of plasma membrane current in Zea mays protoplasts. Plant J. 4: 41-46.

Shutian R, O' Donoghue JA, Larson SM, Finn RD, Jungbluth A, Welt S, Humm JL (2000) Optimizing the sequence of combination therapy with radiolabeled antibodies and fractionated external beam. J. Nucl. Med. 41: 1905-1912.

Walter J, Fluhrer R, Hartung B, Willem M, Kaether C, Capell A, Lammich S, Multhaup G, Haass C (2001) Phosphorylation regulates intracellular trafficking of beta-secretase. J. Biol. Chem. 276: 14634-14641.

Zhu H, Baxter LT, Jain RK (1997) Potential and limitations of radioimmunodetection and radioimmunotherapy with monoclonal antibodies. J. Nucl. Med. 38: 731-741. 
Table 1: List of antibodies tested for antibody penetration into plant protoplasts.

Target protein

\begin{tabular}{llll}
\hline HaWLIM1 & Polyclonal (Rabbit) & CovaLab (Lyon, France) & $1: 1000$ \\
\hline $\begin{array}{l}\text { Recombinant } \\
\text { calreticulin }\end{array}$ & human & Polyclonal (Rabbit) & ABR (Golden, CO, USA) \\
\hline $\begin{array}{l}\text { Chicken erythrocyte } \\
\text { spectrin }\end{array}$ & Polyclonal (Rabbit) & $\begin{array}{l}\text { Sigma-Aldrich (L'Isle 1:40 } \\
\text { d'Abeau Chesnes, France) }\end{array}$ \\
\hline Cdc2 p34 (PSTAIRE) & Polyclonal (Rabbit) & $\begin{array}{l}\text { Tebu (Santa-Cruz, CA, 1:50 to 1:1000 } \\
\text { USA) }\end{array}$ \\
\hline$\alpha$-tubulin & $\begin{array}{l}\text { Monoclonal } \\
\text { (Mouse) }\end{array}$ & $\begin{array}{l}\text { Amersham (Little Chalfont, 1:100 } \\
\text { UK) }\end{array}$ \\
\hline
\end{tabular}

Table 2: Effect of anti-HaWLIM1 antibodies on the actin network and plating efficiency of protoplasts in culture. The percentage of protoplasts displaying an actin network was assessed after a 24 hour treatment with anti-HaWLIM1 antibodies. The division rate was assessed after 4 days in culture in the presence of the antibody. Controls were carried out with the pre-immune serum. Data are expressed as percentages of protoplasts showing a well organized actin network $(\mathrm{N}=160)$ and as percentages of divided protoplasts $(\mathrm{N}=1200)$.

\section{Control}

\begin{tabular}{lll}
\hline Actin network & $80 \pm 3.5$ & Assay \\
\hline Division rate (day 4) & $24.1 \pm 1.1$ & $22.9 \pm 4.1$ \\
\hline
\end{tabular}



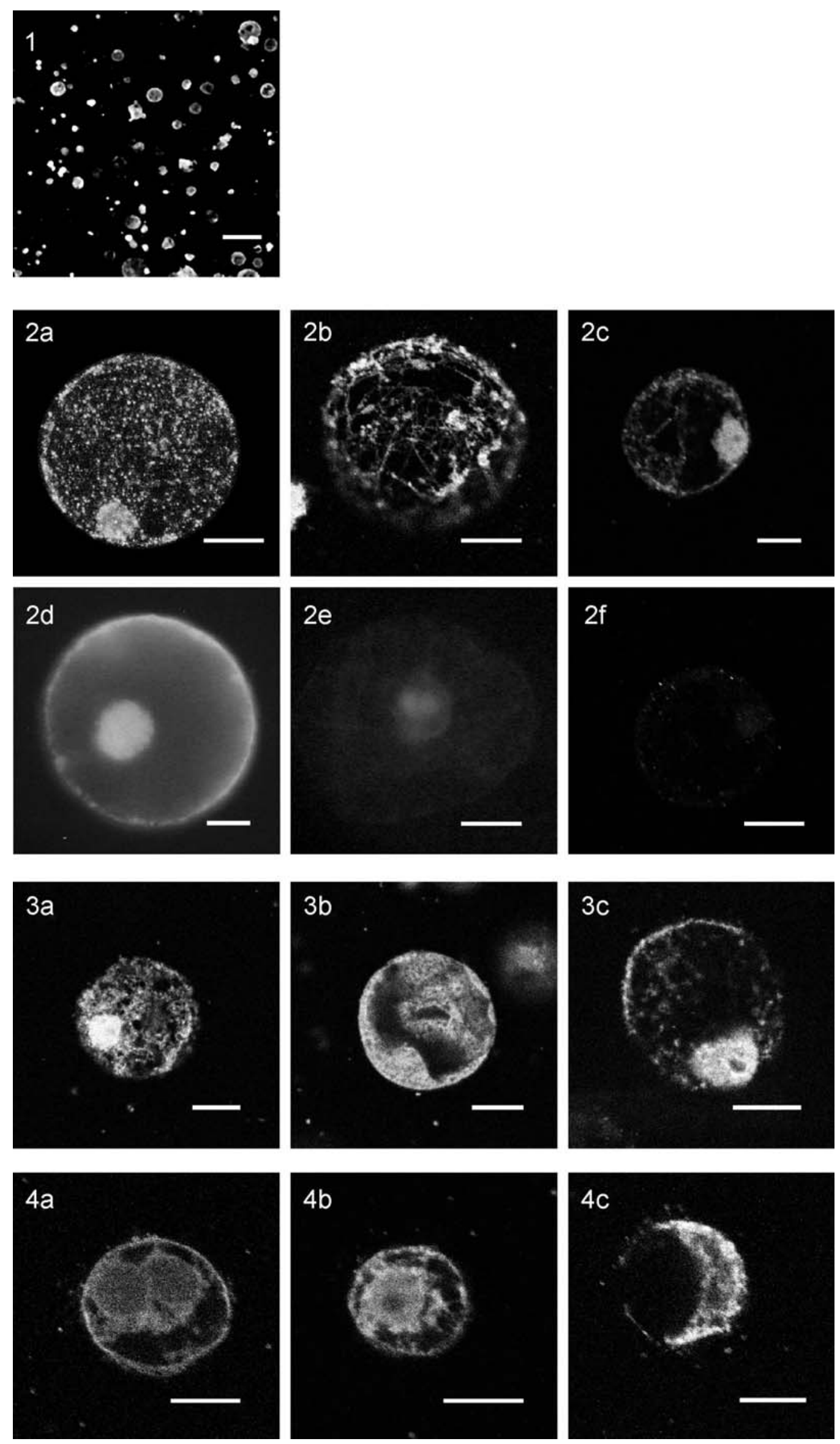
Figure 1. Antibody uptake in sunflower protoplasts preincubated in vivo with anti-HaWLIM1 antibody and stained with FITC-conjugated secondary antibody. Projection of 20 confocal sections (total thickness $80 \mu \mathrm{m})$. Bar $=100 \mu \mathrm{m}$

Figure2. Antibody uptake in sunflower protoplasts. Protoplasts were preincubated in vivo with (a) antiHaWLIM1, (b) anti-spectrin, (c) anti-calreticulin, (d) anti-Cdc2 and (e) anti- $\alpha$-tubulin antibodies. (f) negative control (no antibody preincubation). After chemical fixation protoplasts were immunostained with FITC-conjugated secondary antibody. (a-c, f) confocal microscopy, (d, e) wide field microscopy. Bar $=10 \mu \mathrm{m}$

Figure 3. Antibody uptake in Arabidopsis protoplasts preincubated with (a) anti-HaWLIM1, (b) antispectrin and (c) anti-tubulin before fixation and immunostaining with FITC-conjugated secondary antibody. Observations in confocal microscopy. Bar $=10 \mu \mathrm{m}$

Figure 4. Antibody uptake in tobacco protoplasts preincubated with (a) anti-HaWLIM1, (b) anti-spectrin and (c) anti-tubulin before fixation and immunostaining with FITC-conjugated secondary antibody. Observations in confocal microscopy. Bar $=10 \mu \mathrm{m}$ 


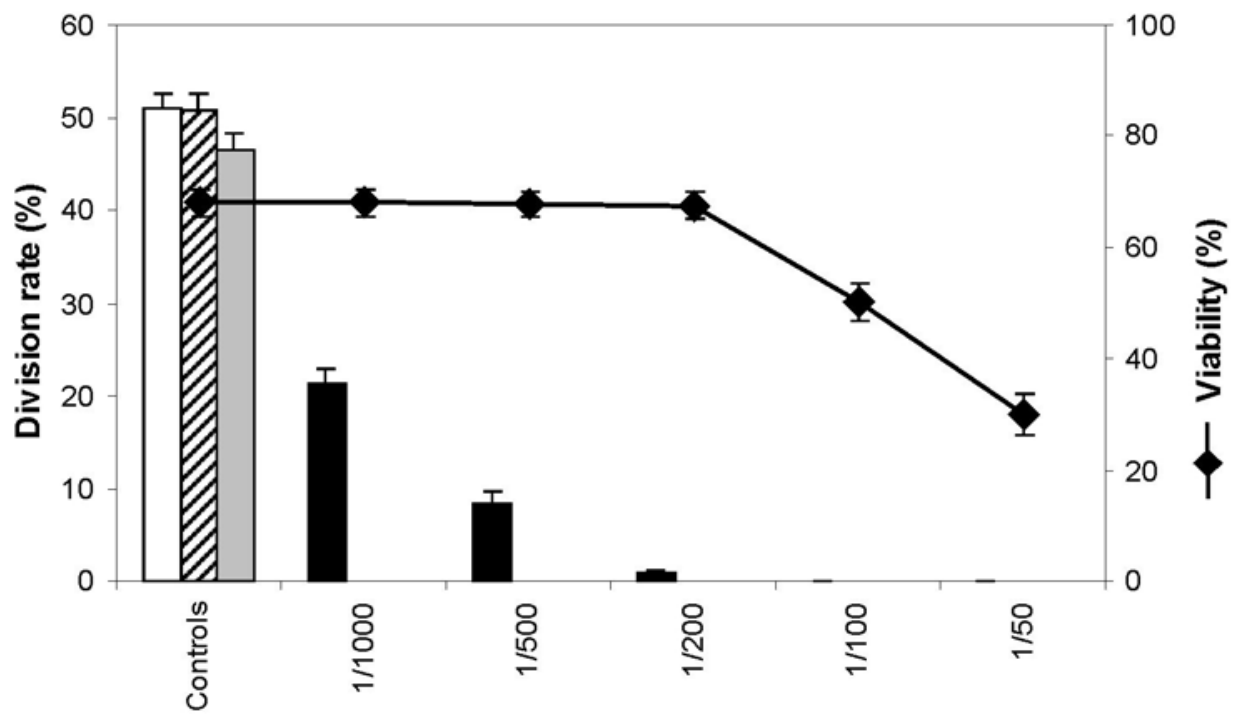

Antibody dilution

Figure 5. Effect of anti-Cdc2 antibody on protoplasts in culture. Division rate (bar chart) and viability ( ) at various dilutions of the antibody. Negative controls: incubation without antibody (empty bar), with preimmune serum 1:500 (stripes) and with preimmune serum 1:100 (grey).

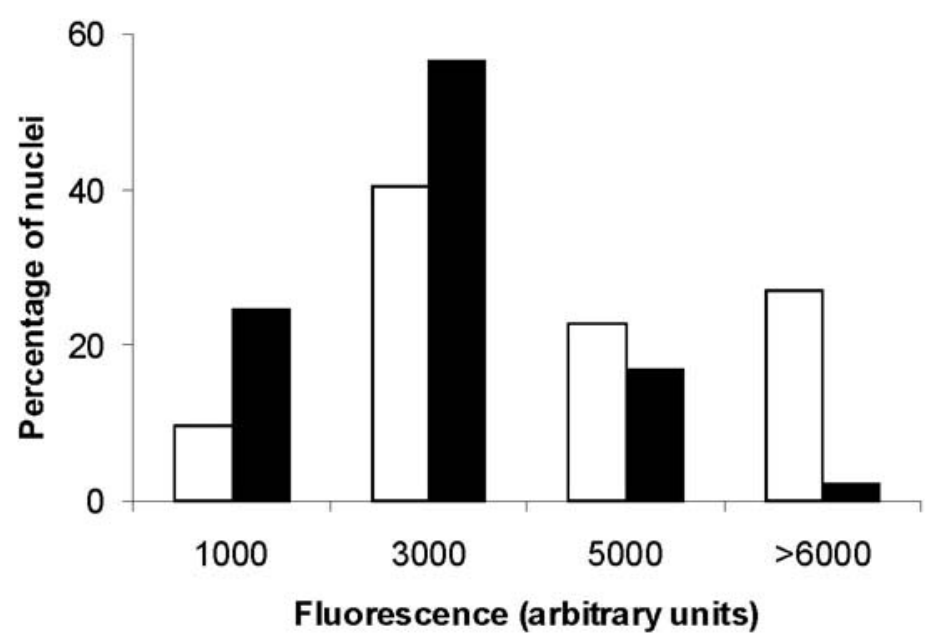

Figure 6. Effect of anti-Cdc2 antibody on the nuclear DNA content of 6 day old undivided protoplasts. Histogram of the fluorescence (in arbitrary units) of nuclei stained with Hoechst 33342, in control conditions (empty bar) and after incubation with anti-Cdc2 antibody 1:500 (black bar). Number of protoplasts measured in each condition: 271 (control) and 191 (treatment). 